\title{
A HISTÓRICA VIOLÊNCIA DE LONGA DURAÇÃO DAS ELITES BRASILEIRAS
}

\author{
A HISTÓRICA VIOLÊNCIA DE LONGA DURAÇÃO DAS ELITES BRASILEIRAS
}

\author{
Lilian Cristina Bernardo Gomes*
}

\section{RESUMO}

Os processos de colonização estão imbuídos de uma violência pela ambição de conquista e acúmulo. No Brasil, isso não foi diferente, e os 350 anos de escravização de negras e negros pelas elites portuguesas é uma marca desse processo. Contudo, mesmo após a Independência (1822), a Abolição da Escravidão (1888) e a Proclamação da República (1889), as próprias elites brasileiras buscaram modos de perpetuar essa violência em função de uma hierarquia social, econômica, política e simbólica com padrões que marcaram a história de longa duração do Brasil pautados no patriarcalismo, patrimonialismo, machismo, sexismo, racismo e homofobia. O presente artigo perpassará diferentes momentos da história do Brasil indicando que as elites brasileiras reinventaram, ao longo da história, formas de perpetuar a violência através da exclusão dos grupos não brancos, estabelecendo hierarquizações e colocando o homem, branco, proprietário e heterossexual no topo da pirâmide num processo de subalternização dos outros grupos.

PALAVRAS-CHAVE: Elites. Racismo. Patriarcalismo. Violência. Subalternização.

\section{ABSTRACT}

The processes of colonization around the world are pervaded by violence that has its roots in the ambition of conquest and accumulation. In Brazil, that was not different and the 350 years of enslavement of black people by the Portuguese elites marks this process. However, even after the Independence of Brazil (1822), Slavery Abolition (1888) and Proclamation of the Republic (1889), the Brazilian elites sought ways in order to perpetuate violence based on social, economic, political and symbolic hierarchy with patterns that marked a longue durée history of patriarchalism, patrimonialism, chauvinism, sexism, racism and homophobia. Thus, the elites naturalized themselves as holders of the power and the market in Brazil. This article will cover different moments in Brazilian history, indicating how the elites they have reinvented, throughout history, ways of perpetuating violence by excluding nonwhite groups, establishing hierarchies and placing the men, not only white, but owner and heterosexual on the top of the pyramid in a process of subalternity of the other groups. KEY WORDS: Elites. Racism. Patriarchalism. Violence. Subalternity.

\footnotetext{
* Pós-Doutorado no Instituto da Democracia e da Democratização da Comunicação (INCT/UFMG). Pósdoutorado em Ciência Política pela UFMG (FAPEMIG, 2010-2011 e CNPQ, 2012-2013). Doutora (2009) e Mestre (2004) em Ciência Política pela UFMG. E-mail: 1cbgomes@ yahoo.com.br.
} 


\section{INTRODUÇÃO}

"Sei que vivemos um momento de desânimo e que o ódio substitui certa bonomia que parecia própria dos brasileiros. É preciso cuidado com cada palavra.” (CARDOSO, 2017). Essa frase do ex-presidente Fernando Henrique Cardoso manifesta uma preocupação de um representante da elite intelectual e política do Brasil com um certo acirramento dos ânimos.

Sem nos determos muito nos desdobramentos dessa percepção, uma coisa é certa: o ódio chega ao Brasil com os colonizadores e desembarca aqui junto com as naus de Cabral com a política mercantilista e a fome por acúmulo de metais preciosos. (NOVAIS, 1969). Esse ódio pode ser estudado sob diferentes formas de violência que interseccionam relações etnicorraciais e de gênero, nos termos de Kimberley Crenshaw (2013), e que se aprofundam no Brasil a partir das práticas do patriarcalismo (MATOS; PARADIS, 2014), do sexismo (CARNEIRO, 2002) e da homofobia (LOURO, 2001), apenas para citar alguns. Acrescenta-se a essas práticas um sistema jurídico voltado para o marco do indivíduo e da defesa da terra que criou uma tradição jurídica de defesa da propriedade privada, jogando diferentes povos e comunidades tradicionais na invisibilidade (ALMEIDA, 1996). O presente artigo abordará diferentes formas de violência praticadas pelas elites ${ }^{1}$, sobretudo aquelas que afetaram o âmbito político, econômico e simbólico.

A violência das elites, desde o início, teve como aporte a associação entre Estado, Igreja Católica e proprietários de terras contra os escravizados, mantendo um modelo masculino, proprietário, escravocrata, heterossexual e branco. O enfrentamento da temática da violência presente na sociedade brasileira é fundamental, bem como é primordial a percepção de Hannah Arendt sobre tal questão quando afirma: "ninguém que se tenha dedicado a pensar a história e a política pode permanecer alheio ao enorme papel que a violência sempre desempenhou nos negócios humanos e, à primeira vista, é surpreendente que a violência tenha sido raramente escolhida como objeto de consideração especial” (ARENDT, 1994, p. 16).

A metodologia utilizada no presente artigo será a de mostrar alguns marcos históricoschave para a compreensão de que a violência das elites foi ativamente produzida no Brasil, tendo se configurado através de uma rigorosa legislação e doutrinação, estabelecida já desde o

\footnotetext{
${ }^{1} \mathrm{O}$ modo de nomeação desses grupos, a partir de então, se reduzirá ao termo elites, mas é importante que se mantenha a percepção de que se trata de parte das elites econômicas, políticas e intelectuais que forneceram as bases para a naturalização do homem, branco, proprietário e heterossexual como o vocacionado aos lugares de poder político, econômico e simbólico.
} 
período colonial, permanecendo no Império e na República, e efetivada por diferentes governos.

Deve-se ressaltar que os marcos escolhidos não tiveram a preocupação em seguir uma cronologia linear e sistemática, mas a de apontar para determinadas ações dessas elites que criaram uma estrutura de violência e desigualdade de longa duração ${ }^{2}$ no Brasil. A primeira seção focaliza o período colonial; a segunda retoma alguns elementos do País pósindependência; a terceira seção tratará "Do movimento abolicionista à reinvenção da violência no pós Lei Áurea (1888) e Proclamação da República (1889) até a década de 1960"; a quarta seção se referirá ao período do Golpe Militar de 1964 aos dias de hoje. Finalmente passar-se-á às Considerações finais.

\section{PERÍODO COLONIAL: A VIOLÊNCIA QUE CHEGOU COM AS CARAVELAS}

A violência da colonização chega com as caravelas e com as ambições do projeto mercantilista de acumulação capitalista no processo de formação dos estados nacionais europeus. Conforme indica Caio Prado Júnior (2000, p. 11): "É sempre como traficantes que os vários povos da Europa abordarão cada uma daquelas empresas que lhes proporcionarão sua iniciativa, seus esforços, o acaso e as circunstâncias do momento em que se achavam".

E essa violência se aprofundou à medida que a ambição por extensas propriedades se aguça entre os portugueses. Inicialmente não foram concedidas grandes extensões, mas implantou-se o sistema de sesmarias no Brasil. Se a determinação de funcionamento das sesmarias tivesse mantido suas características iniciais, o modo de percepção das terras no Brasil poderia ter seguido outro rumo, diferente daquele pautado na grande propriedade de terras que acabou por predominar. No entanto, uma série de desvirtuamentos no sistema de sesmarias fez com que, ao final dessa Lei — com o processo de Independência em 1822 —, esse sistema já tivesse aberto caminho para o estabelecimento do latifúndio. Pelo menos dois

\footnotetext{
2 "Longa duração" está inspirado no termo cunhado por Fernand Braudel la longue durée. O autor desenvolve esse conceito em sua tese de doutorado publicada em 1949 La Mediterranee et le monde mediterraneen a 1 'epoque de Philippe II na qual faz um estudo do espaço e do tempo histórico. O conceito de longa duração passou a ser fundamental para a teorização das Mentalidades: "concebidas como estruturas de crenças e comportamentos que mudam muito lentamente, tendendo por vezes à inércia e à estagnação.” Contudo, embora Braudel tenha fornecido "instrumentos teóricos para os futuros historiadores das mentalidades, 'a era Braudel' foi em tudo avessa ao estudo do mental” (CARDOSO; VAINFAS, 1997, p. 200). Neste artigo, o uso do termo tem o objetivo de mostrar que a estrutura de crenças e comportamentos das elites brasileiras, ao longo do período colonial, imperial e republicano, tendeu à inércia, praticamente à estagnação quando a estrutura de privilégios se mantinha a mesma, mas diante das ameaças de perda do status quo, as elites refizeram suas práticas para a manutenção de um modo privatista de conduzir os rumos econômicos, políticos e simbólicos do Brasil.
} 
aspectos que levaram a esses desvirtuamentos podem ser citados. O primeiro está relacionado às primeiras ações da Coroa portuguesa que, em 1530, envia Martim Afonso de Sousa determinando que ele concedesse sesmarias e, já em 1532, estabelece uma nova determinação para o sistema de distribuição de terras, que seria a divisão do Brasil em Capitanias Hereditárias.

Isso nos leva ao segundo aspecto desse desvirtuamento, ou seja, a perpetuação da prática do patrimonialismo - já em voga em Portugal (FAORO, 2000) - segundo a qual a Coroa Portuguesa utilizava o seu patrimônio para obter apoio do clero, da nobreza e da alta burguesia, ou para premiar vassalos mais fiéis. No Brasil, essa prática foi reproduzida pelos donatários de terras ou pelos funcionários da Coroa (RIGATTO, 2006). Essa prática secular de troca de algum favor por outro benefício, chamada de corrupção, está desde o processo de formação do Brasil (FIGUEIREDO, 2008).

Assim, na Colônia, se forma uma rede de poder que liga Igreja Católica, elite rural e funcionários da Coroa Portuguesa (MARX, 1998) que estabelecem relações privilegiadas que permitiam às elites rurais não apenas se apossar das melhores terras, mas também aprender a dominar o sistema de sua distribuição, tornando cada vez mais difícil o acesso a terras por outros grupos, mesmo se para isso fosse necessário fazer uso da violência. Holston (1993) indica que a estratégia das elites não foi a de negar a lei, mas, ao contrário, que as elites agrárias mandavam seus filhos estudarem Direito na Universidade de Coimbra e eles, ao retornarem, ocupavam os altos escalões das carreiras políticas e jurídicas. O autor afirma que: “[...] a elite tinha aprendido a complicar o sistema jurídico e disso tirar vantagens" (HOLSTON, 1993, p. 80).

Contudo, se por um lado os proprietários tornam-se cada vez mais poderosos e ambiciosos, por outro lado as diferentes formas de resistência também se manifestavam. Mesmo em meio a um forte processo da aculturação efetuada pelos jesuítas, os indígenas mantiveram, por exemplo, suas práticas da antropofagia, da embriaguez pelo cauim, da poligamia e a inspiração do fumo queimado nos maracás (BOSI, 1992). Tudo isso produziu não a catequese ensaiada nas naus e tão bem instruída por Inácio de Loyola, e desejada pelo catolicismo oficial, como afirma Bosi, mas um sincretismo que depois se torna ainda mais forte com as religiões africanas e de matriz afro.

Outras formas de resistência ocorreram como, por exemplo, com os Tupinambás que eram exímios na arte da guerra. Florestan Fernandes (1952) apresenta um trecho do Tratado Descritivo do Brasil escrito em 1587 por Gabriel Soares de Souza em que ele diz: "Como os 
tupinambás são muito belicosos, todos os seus fundamentos são como farão guerra aos seus contrários". (FERNANDES, 1952, p. 389). E nessa obra Fernandes perpassa detalhadamente as (1) armas utilizadas pelos Tupinambás; (2) como organizavam as expedições guerreiras e suas motivações; (3) o profundo conhecimento do território e como usá-lo para não permitir que os portugueses ficassem em algum lugar. Enfim, a arte que dominavam era bastante sofisticada em diversos aspectos que não nos é possível delongar aqui, mas que fornece elementos para compreendermos que os portugueses tiveram sérias dificuldades quando a decisão dos Tupinambás e de outros grupos indígenas era manter-se ou conquistar determinado território. Contudo, é preciso lembrar que essa resistência foi necessária como defesa após a histórica ação etnocida dos portugueses em relação aos indígenas, que continuou no Império e na República.

\section{O PÓS-INDEPENDÊNCIA E O REFORÇO DOS MECANISMOS DE VIOLÊNCIA CONTRA OS NÃOPROPRIETÁRIOS}

Nessa mesma tendência, uma das medidas mais emblemáticas foi a do Primeiro Governo do pós-Independência (1822), a Constituição de 1824. Elaborada sob o forte autoritarismo de D. Pedro I, ficou conhecida como "A Outorgada". Contudo, nessa seção o foco recairá na Lei de Pena de Morte aos Réus Escravos (10/06/1835) que exemplifica bem o modo pelo qual o Estado criava novas leis que garantiam os direitos das classes abastadas e suas famílias, não se eximindo para isso do uso abusivo da violência, sobretudo, com os escravizados.

A multiplicidade de penas do Código Criminal do Império do Brasil (1830) ${ }^{3}$ não foi suficiente para manter o clima de segurança desejado pelas elites abastadas e apoiadas pelo Estado. O título do livro de Celia Maria Marinho de Azevedo (2004) expressa bem o que se passava naquele momento Onda negra, medo branco. A classe proprietária estava atemorizada com a revolta dos escravos de São Domingos, atual Haiti, bastante receosa de que algo semelhante pudesse ocorrer no Brasil. Conforme afirma Ribeiro (2005, p. 43). : “[...] o perigo, se raras vezes real, sempre era potencial como mostram as inúmeras conspirações e insurreições na Bahia, de 1807 a 1835".

\footnotetext{
${ }^{3}$ O Código Criminal do Império do Brasil de 1830 já previa: pena de morte (art. 38); galés, temporárias ou perpétuas (art. 44); prisão com trabalho, temporária ou perpétua (art. 46); prisão simples, temporária ou perpétua (art. 47). Embora as penas não se destinassem apenas aos escravos, era nítida uma preocupação em garantir a punição a estes (RIBEIRO, 2005, p. 21ss.).
} 
Um exemplo de um real e potencial perigo ocorreu em Carrancas, pertencente à Vila de São João d'el Rei, que foi palco de uma insurreição escrava no dia 13 de maio de 1833. Ribeiro inclusive indaga se ao assinar a Lei Áurea em 13 de maio de 1888 a Princesa Isabel não estaria se lembrando da insurreição dos escravos ocorrida no mesmo dia no ano de 1833. (RIBEIRO, 2005, p. 5). O autor descreve com detalhes o assassinato de filhos, netos, sobrinhos, noras, genros e agregados do deputado Gabriel Junqueira, que foram mortos por seus escravizados, instigados por diferentes rumores, um deles com uma informação de um passageiro desconhecido que disse aos escravizados que no Rio de Janeiro "os escravos todos tinham morto os senhores, estavam no gozo de seus bens, e que admiravam que em Minas não tivessem feito outro tanto". (RIBEIRO, 2005, p. 45).

Ao final o conflito foi debelado com a prisão dos insurgentes. Foram julgados 33 escravizados, sendo a maioria condenada à morte. Os julgamentos se deram pelo Código Criminal do Império de 1832. O que se segue é uma proposta de Lei no mês seguinte ao ocorrido em Carrancas. Após tramitação por dois anos e, sobretudo, depois da Revolta dos Malês ocorrida na noite de 24 para 25 de janeiro de 1835, houve um apelo do Ministro da Justiça para que a Assembléia Geral: "não deixasse esse negócio em abandono, pois o Brasil se compõe de diversas castas, cujas intenções são permanentemente hostis e tendentes a desordens; o Governo necessita de meios capazes de as fazer abortar o seu germe, as sufocar no rompimento". (RIBEIRO, 2005, p. 65).

Esse apelo do Ministro da Justiça foi ouvido e, em apenas uma sessão ${ }^{4}$, foi aprovada, em 15 de maio de 1835, a Pena de Morte aos Réus Escravos. Ribeiro (2005) conclui que pouca foi a utilidade da Lei para o combate às insurreições, tendo servido, outrossim, para instaurar o que ele nomeia de uma tradição funesta que aprofunda as contradições entre liberalismo e escravidão.

Depois dessa Lei muitas outras insurreições de escravizados ocorreram no período Regencial (1831-1840) e no Segundo Império (1840-1889). O que se observa é que se o Estado negava a existência política dos escravizados e a maior parte das normas - pelo menos até a segunda metade do século XIX - era para reprimi-los. Por sua vez, esses escravizados agiam em muitas ocasiões ignorando, na medida do possível, esse mesmo Estado que não os reconhecia como seres humanos. Isso acontece, por exemplo, com as comunidades de quilombo que durante todo o período colonial e imperial foram perseguidas e consideradas

\footnotetext{
4 “A Câmara dos Deputados aprova o projeto vindo do Senado sem modificá-lo - lei de exceção." (RIBEIRO, 2005, p. 65).
} 
subversões à ordem, como bem demonstra a vasta historiografia sobre o tema. (MOURA 1983; GOMES, 2006; REIS 1996). No entanto, feita a Abolição e proclamada a República, não existe a ocorrência de legislação republicana que redefina a categoria quilombo ou que repense os desdobramentos dessa experiência no cenário nacional até 1988. (ALMEIDA, 1996, p. 12-15). Embora, como experiência concreta, continuassem a reproduzir, nas diversas territorialidades, seus modos de criar, fazer e viver, os quilombos ficaram invisibilizados do espaço público como questão nacional até a Constituição Federal de 1988.

O que se observava e que ficará bem expresso nas leis que se seguem antes e depois da Abolição é que pensar o Brasil, com tamanhas desigualdades, cairá como um peso nos ombros de juristas e não juristas, intelectuais e políticos que discutiam e tinham um leque de alternativas. Mas as escolhas feitas acabaram por aprofundar essas desigualdades e afastar o Brasil real do Brasil imaginado a partir dos padrões do Norte Global.

Isso fica nítido, por exemplo, nas opções feitas na Lei de Terras de 1850 - no mesmo ano da Lei Eusébio de Queiroz, que coloca fim ao tráfico de escravos - que já antevê o futuro cidadão que se quer, ou seja, aquele que tenha posses para adquirir terras, excluindo aqueles que seriam libertos com o fim da escravidão já que a Lei de Terras estabeleceu a ligação entre terra e mercado (GOMES, 2009).

\section{DO MOVIMENTO ABOLICIONISTA À REINVENÇÃO DA VIOLÊNCIA NO PÓS- ABOLIÇÃO E PROCLAMAÇÃ̃ DA REPÚBLICA ATÉ A DÉCADA DE 1960}

A ebulição na segunda metade do século XIX tornou-se forte com a Campanha Abolicionista que ganhou as ruas. Isso coloca em disputa diferentes projetos que indicavam que país se queria construir no pós-escravidão. Pelo menos dois projetos se apresentam com cores mais fortes: de um lado, havia o projeto dos abolicionistas radicais como Luís Gama e outros projetos de cunho liberal para colocar fim à escravidão. (MATTOS, 2000). De outro lado, desenhava-se outro cenário com a entrada das teorias raciais importadas da Europa e que terá, posteriormente, na figura de intelectuais do porte de Silvio Romero, Oliveira Viana e Nina Rodrigues, importantes pensadores que se colocaram a tarefa de pensar o Brasil branco, tendência essa que aprofundaria as hierarquizações sociais, com a afirmação do preconceito racial e da ordem social iníqua. (SKIDMORE, 1976).

O que se viu nos anos subsequentes à Abolição foi a vitória dessa última tendência que passa a identificar o Brasil com o branqueamento. Bosi afirma que aquele que estudasse a 
história do negro e do mestiço pós Abolição teria que desfazer um outro nó: "não o que atou liberalismo e escravidão, mas o que, até hoje, ata liberalismo a preconceito". (BOSI, 1992, p. 245). Ou seja, o País livre e em seguida republicano aprofundará as hierarquizações raciais e sexuais: o homem branco, proprietário e patriarca mantém-se como uma espécie de vocacionado natural aos lugares de negócio e da política, enquanto às mulheres estava reservado o papel de sujeição e aporte para que os homens exercessem as atividades públicas. Isso nos remete à autora Carole Pateman quando afirma que as mulheres não participam do contrato original, e que o contrato sexual é o meio pelo qual os homens transformam seu direito natural sobre as mulheres na segurança do direito patriarcal civil. (PATEMAN, 1993, p. 21). Sem adentrar nos meandros desses elementos do contrato, o que se quer destacar é que sejam as mulheres as nomeadas "raças menos fecundas", o lugar a ocupar estava definido: o da sujeição.

A posição de Oliveira Viana em Evolução do povo brasileiro expressa bem como se concebia nesse momento o modo de ordenamento social:

\footnotetext{
Quando duas ou mais raças, de desigual fecundidade em tipos superiores, são postas em contacto num dado meio, as raças menos fecundas estão condenadas, mesmo em hipótese da igualdade do ponto de partida, a serem absorvidas ou, no mínimo, dominadas pela raça de maior fecundidade. Esta gera os senhores; aquelas, os servidores. Esta, as oligarquias dirigentes: aquelas, as maiorias passivas e abdicatórias. (VIANA, 1938, p. 173).
}

Atestando-se uma valorização nesse momento da entrada de "raças fecundas", onde se pode ler "brancos", há logo após a Proclamação da República a promulgação do Decreto n 528 de 1890 que regulamentava a entrada de imigrantes no Brasil e no art. 20 apontava: "Todo o proprietário territorial, que desejar collocar immigrantes europeus em sua propriedade, tem direito aos favores constantes deste decreto." O que nos parece relevante é o fato de que havia uma disposição firme dos republicanos de atrair imigrantes brancos para o País. Ou seja, os ex-cativos que não eram cidadãos na Colônia e no Império, mas a mão de obra primordial para o trabalho no Brasil, agora eram preteridos para a produção.

Isso nos leva ao questionamento de uma constatação já feita: será que sendo ignorada pelo Estado essa população - seja a ex-cativa ou setores pobres que poderiam ser utilizados como mão de obra, também -, não se tornava indiferente a esse mesmo Estado? Isso nos direciona à frase de Aristides Lobo, fervoroso propagandista da República que questiona o porquê no momento da Proclamação da República: ““o povo assistiu a tudo bestializado’, sem 
entender o que se passava, julgando talvez assistir a uma parada militar." (CARVALHO, 1987, p. 9).

A ideia construída, sobretudo, no período getulista (1930-1945), qual seja, a de que a Primeira República foi uma "República Velha", é uma formulação que desqualifica todo o potencial de resistência manifesto, nesse momento, seja dos capoeiros (WISSENBACH, 1998), seja na Revolta da Vacina (CARVALHO, 1987) seja na "construção da identidade coletiva da classe trabalhadora" (GOMES, 2005, p. 8), apenas para citar algumas formas de resistência. Essa desqualificação é parte do bem montado projeto estatal do getulismo, fazendo parecer que "no Brasil o trabalhador obteve por outorga do poder público, sem lutas, os benefícios que tanto custaram a outros povos”. (GOMES, 2005, p. 206).

Entretanto, não se pode negar que predominou uma ideia de que na Primeira República a "questão social era um caso de polícia" 5 , de que o povo era uma massa a ser educada e, ainda, de que a entrada das teorias raciais e do projeto de embranquecimento tinha surtido efeitos. Soares (2008, p. 101) indica que o censo de 1890 apontava que $56 \%$ dos brasileiros eram negros e já o censo de 1940 indicava que a população negra era de 35,8\%), e ele argumenta que uma das hipóteses explicativas foi a entrada de três milhões de europeus de 1890 a 1930.

No que se refere a essa última questão, qual seja, a valorização do branqueamento, pode-se identificar uma virada no modo de pensar a sociedade brasileira: o movimento modernista, com a simbólica Semana de Arte Moderna em 1922, contribuiu para a mudança no modo de percepção da mestiçagem e dos elementos não brancos ao não serem vistos apenas na vertente da vergonha nacional e, embora o próprio Mario de Andrade, ao final da vida, tenha se ressentido de que houve um certo "abstencionismo" em relação aos reais problemas da sociedade identificando que os modernistas estavam eivados de um “aristocracismo" (ANDRADE, 1990[1942], p. 36), eles contribuíram de alguma forma para

\footnotetext{
5 "Todo esse período foi marcado por um sem-número de exemplos de brutalidade repressiva, orientação professada pelos governantes, apoiada por industriais e fazendeiros e muito bem resumida pelo presidente Washington Luís (que fora Secretário da Justiça e da Segurança Pública do Estado de São Paulo) quando definiu a 'questão social' - que era como então se chamavam os conflitos sociais - como 'caso de polícia'. Foi assim na greve de operários numa fábrica de sapatos no Rio de Janeiro, em 1902; no movimento grevista na Cia. Doca de Santos, em 1904; na greve de ferroviários paulistas, em 1906; na Revolta da Chibata, em 1910, quando marinheiros negros e mulatos rebelaram-se contra o uso do chicote como instrumento de punição na Marinha; em Juazeiro e no Contestado; na greve de colonos das fazendas de café da região de Ribeirão Preto, em 1913; na primeira greve geral que parou cerca de 50 mil trabalhadores da cidade de São Paulo, em 1917; na greve da Cia. Mogiana, em 1920, e assim por diante. A partir de então intensificaram-se as práticas repressivas, pois 'a piedosa simpatia pelos 'deserdados da fortuna', pelos 'humildes', por aqueles que os 'maus fados' haviam irremediavelmente fixado no fundo dos estratos da sociedade, começa a converter-se em inquietude quando a desarticulada massa ameaça ultrapassar os limites e transformar-se em classe social” (PATTO, 1999, p. 172).
} 
alterações na percepção dos grupos até então subalternizados. Eles olharam para a Floresta Amazônica, para os indígenas e afros e, embora exaltando seu exotismo, pelo menos, era um olhar para dentro (BROOKSHAW, 1983). Alguns trechos do Manifesto Antropófago indicam essa virada para um Brasil visto de dentro: "Contra todos os importadores de consciência enlatada [...] Nunca fomos catequizados. Fizemos foi o Carnaval. O índio vestido de senador do Império [...]. Já tínhamos o comunismo. Já tínhamos a língua surrealista. A idade de ouro [...] Antes dos portugueses descobrirem o Brasil, o Brasil tinha descoberto a felicidade." (ANDRADE, 1990).

Podemos dizer que essa valorização do Brasil real foi fundamental para uma leitura de nossa formação como um elemento de originalidade nacional. A afirmação de nossa mistura como originalidade se dará de modo mais categórico, posteriormente, com as ideias de Gilberto Freyre. Esse autor foi central para tirar a mestiçagem do lugar da vergonha para o do orgulho nacional. Com a obra Casa grande e senzala (1936), Freyre rompe com a tendência, predominante até aquele momento, que analisava a questão racial no Brasil a partir das teorias importadas da Europa e centravam o debate em um conteúdo biologizante e o branqueamento como a salvação da raça brasileira. Desse modo, Gilberto Freyre introduziu outro parâmetro na análise da sociedade, o que faz com que o discurso do racismo científico perca sua centralidade. No entanto, embora reconhecendo esse inegável papel de Freyre, é visível o impacto desse pensamento para o debate de uma identidade nacional que se consolida, cada vez mais, a partir da preponderância da matriz ocidental pautada na ideia iluminista de civilização, o que contribuiu para a consolidação de uma hierarquização social na qual o branco estava no topo da pirâmide social, apesar da valorização da mestiçagem.

Essa leitura do Brasil passa a ser amplamente apropriada pelo governo getulista, que em um movimento nacionalista alça a cultura mestiça como a representação oficial da nação. Por exemplo, a capoeira, incluída como crime no Código Penal de 1890, é oficializada como modalidade esportiva nacional em 1937. Também o samba passou da repressão à exaltação, de "dança de preto" a "canção brasileira para exportação"6. (SCHWARCZ, 1998).

No entanto, a denúncia feita pelos movimentos sociais negros, desde Abdias do Nascimento e Guerreiro Ramos com a Frente Negra Brasileira (1931), com o Teatro Experimental do Negro (1944) e, sobretudo, a partir da década de 1970, é a de que essa

\footnotetext{
${ }^{6}$ Enquanto as escolas de samba e desfiles passam a ser oficialmente subvencionados a partir de 1935, também é instituído o dia da Raça (30 de maio de 1937) como forma de exaltar a tolerância em nossa sociedade. Para aprofundamento ver Schwarcz (1998).
} 
exaltação da mestiçagem e da cultura negra não mudou os patamares de desigualdade racial e do sexismo. Por isso, os movimentos sociais negros passaram a usar a expressão "raça social" para expressar que há uma desigualdade de cunho racial e que a mestiçagem de certo modo dificultou a politização e a denúncia dessas desigualdades, através do mito da democracia racial.

O início da década de 1960 emanava ares de liberdade e emancipação. Fazia parecer que finalmente o Estado realizaria as tão esperadas reformas de base voltando-se finalmente para o Brasil real. Um dos sinais mais emblemáticos dessa possibilidade de marcha para uma sociedade mais justa e igualitária foi a nomeação de Paulo Freire para levar à frente o Plano Nacional de Alfabetização ${ }^{7}$. Contudo, a forte ancoragem das classes proprietárias com as forças conservadores e estruturantes do País, em conexão com o imperialismo norteamericano, frustraram essa marcha com o Golpe de 1964.

\section{TRADIÇÃO, FAMÍLIA E PROPRIEDADE COMO FORMAS DE AFIRMAÇÃO DA VIOLÊNCIA: DOS GOLPES DA ELITE BRASILEIRA}

A opção por tratar em um mesmo item do Golpe Militar de 1964 aos dias de hoje embora se saiba que a partir de 1984 tenha se reiniciado a experiência democrática no Brasil com avanços significativos, sobretudo com a Promulgação da Constituição de 1988 - explicase por pelo menos três aspectos que auxiliam na compreensão de inúmeros retrocessos e pautas conservadoras que vieram à tona, principalmente a partir de 2015 . O primeiro está ligado a uma hipótese sustentada neste artigo, qual seja: que a não efetivação de uma justiça de transição $^{8}$ fez com que a população não tivesse a dimensão precisa do que foi o Golpe Militar e as consequentes violações de direitos humanos. Apenas para citar um exemplo: a não formação de um tribunal que julgasse os crimes de tortura e assassinatos ocorridos nesse período implica que não se tenha desenvolvido a dimensão exata do que foi o Período Militar e seus porões do terror. O segundo aspecto é que hoje, assim como no momento do Golpe

\footnotetext{
${ }^{7}$ Programa criado através do Decreto no 53.465 , de 21 de janeiro de 1964. Sua instituição foi uma tentativa do Ministério da Educação e Cultura de coordenar os movimentos de educação de base e/ou alfabetização de adultos e adolescentes que vinham-se multiplicando em todo o país a partir de 1961.

${ }^{8}$ Uma efetiva justiça de transição envolve a adoção de um conjunto de medidas legais, políticas e institucionais pelos governos pós-ditatoriais, como por exemplo (1) a instauração de uma Comissão da Verdade destinada à investigação dos fatos relacionados à repressão política e à publicação de um relatório oficial de acesso público com as informações averiguadas pela Comissão; (2) a responsabilização civil, administrativa e, sobretudo, penal dos agentes públicos envolvidos nas violações de direitos humanos; (3) a criação de políticas de reparação das vítimas (restituição, compensação/indenização, reabilitação e garantia de não repetição). (VASCONCELOS, 2015, p. 21).
} 
Militar que derrubou João Goulart em março de 1964, são mobilizados dois argumentos que justificam tal ação: o combate à corrupção ${ }^{9}$ e a cultura política de longa duração no Brasil do anticomunismo $^{10}$.

$\mathrm{O}$ último aspecto está ligado às marchas conservadoras, as quais culminaram com a "Marcha da Família Com Deus pela Liberdade" ocorrida em março de 1964 (GUISOLPHI, 2017). Elas retomavam o papel que a tradição e a família - como grandes baluartes da afirmação do homem, branco, proprietário e heterossexual - tinham como uma forma de retomar o lugar "naturalizado" desses grupos ao poder e ao topo da hierarquia social e da recuperação por estes da posição de comando político, que vinha sendo ameaçada pelas propostas das reformas de base, da educação libertadora de Paulo Freire, pela força das Ligas Camponesas, dentre outras. A Lei de Segurança Nacional desempenhou papel central nessa retomada de longa duração do modo de conceber as normas que regem o Brasil.

A Escola Superior de Guerra (ESG) ${ }^{11}$ teve um papel central na disseminação de: "um pensamento acerca da segurança nacional e das formas de combater ameaças ao projeto implementado numa parceria entre militares e civis". (FONTELES DUARTE, 2014, p. 80). A ideia principal era alcançar a mobilização das elites para frear as ameaças ao projeto da família tradicional, religião Católica e defesa da propriedade. A autora indica que entre 1950 e 1967 50\% dos alunos da ESG eram civis, e vários ocuparam postos importantes no regime e em instituições políticas e econômicas brasileiras.

O cultivo da virtude das crianças e dos jovens e do papel da mulher no lar era ressaltado nos estudos. O tema da mulher e o mercado de trabalho e do divórcio passaram a

\footnotetext{
${ }^{9}$ Starling (2008) indica de que modo os militares foram malsucedidos no propósito de combate à corrupção. A autora afirma: "O regime militar conviveu tanto com os corruptos e com sua disposição de fazer parte do governo fosse qual fosse sua natureza política, quanto com a face mais exibida da corrupção, que graças aos dribles da censura foi capaz de chegar às páginas dos jornais e compor a lista dos grandes escândalos de ladroagem da ditadura - como ocorreu, por exemplo, entre vários outros episódios que ficaram célebres, como o escândalo do Instituto Brasileiro do Café; o caso Hanna Mining Company; o caso Delfin; o Projeto Jari; a construção da ponte Rio-Niterói e da Transamazônica; a operação Capemi." (STARLING, 2008, p. 253).

${ }^{10}$ Motta (2010) indica que "o anticomunismo surgiu como resposta ao desafio real implicado na existência do projeto comunista; porém, ao mesmo tempo, as representações contra o comunismo divulgadas na sociedade contribuíram para ampliar a percepção da presença do "perigo", gerando, por vezes, uma relação desproporcional entre a força efetiva dos revolucionários e o medo neles inspirado. A preocupação em não perder de vista o impacto real do anticomunismo levou a uma estrutura de tese convergindo para os golpes autoritários de 1937 e 1964, eventos em que a mobilização contrarrevolucionária foi fator chave. De fato, as duas "grandes" ditaduras brasileiras do século XX evidenciam a importância do fenômeno anticomunista, já que parcela significativa dos golpistas mobilizou-se, nos respectivos contextos, para lutar contra o perigo vermelho". (MOTTA, 2010, p. 20).

${ }^{11}$ A Escola Superior de Guerra (ESG) foi criada em 1949, no âmbito da Guerra Fria e ligada ao Ministério da Defesa.
} 
ser recorrentes. Em texto da ESG fica explícito que a realização individual dos cônjuges era um desvirtuamento.

[...] felicidade no casamento não implica na ausência de sofrimento e até requer dos cônjuges muita capacidade de sacrifício. É preciso que eles saibam sofrer para poderem ser felizes, e só serão desde que, das contradições encontradas na vida conjugal, se sirvam não para poder criar uma hostilidade recíproca, mas para purificar e fortalecer o seu amor. O casamento não é para o amor, mas o amor é para o casamento. Este foi instituído para a transmissão da vida, e uma lei providencial suaviza os deveres decorrentes desse estado, pelo sentimento do amor. A função do casamento transcende, pois, a esfera da estreita satisfação dos cônjuges, e interessa o bem da humanidade. (BRASIL/ESG, 1975, p. 11 apud FONTELES DUARTE, 2014).

Essa pauta da família e dos princípios morais tem sido retomada com ênfase, sobretudo, a partir de 2015, com as polêmicas acerca do debate sobre educação, gênero e sexualidade na escola e as proibições a exposições de arte e teatros, repressões feitas sob a alegação de que tais eventos promovem valores que não são bem-vindos no seio da tradicional família brasileira. Dados os limites deste artigo, não há espaço para aprofundamento desse tema, mas o que se quer mostrar é que a Doutrina de Segurança Nacional, difundida pela ESG ainda continua a ser bem-sucedida, sobretudo na criação dos filhos brancos da elite que são naturalizados como aqueles a ocuparem os cargos de poder e da economia, relegando à população não branca os lugares da invisibilidade e da violência. $\mathrm{O}$ Atlas da Violência (2017) revela que homens, jovens, negros e de baixa escolaridade são as principais vítimas de mortes violentas no País. A população negra corresponde à maioria $(78,9 \%)$ dos $10 \%$ dos indivíduos com mais chances de serem vítimas de homicídios. Atualmente, de cada 100 pessoas assassinadas no Brasil, 71 são negras. De acordo com informações do Atlas, os negros possuem chances 23,5\% maiores de serem assassinados em relação a brasileiros de outras raças, já descontado o efeito da idade, escolaridade, do sexo, estado civil e bairro de residência. Como tem sido indicado neste artigo, as desigualdades de gênero e raça, dentre outras desigualdades, também contribuem para essa distância entre brancos e negros, com um bem montado projeto de sociedade que legitima no topo da hierarquia a elite brasileira, aprofundando as desigualdades raciais.

A década de 1970 trouxe novos ares emancipatórios com uma pluralidade de movimentos sociais, com a denúncia de que o Estado brasileiro é autoritário/ patriarcal (MATOS; PARADIS, 2014), etnocida (NASCIMENTO, 1980), racista (MUNANGA, 2004) e sexista (CARNEIRO, 2002). A Constituição Federal (CF) de 1988 incorpora muitas dessas 
denúncias com leis que reconhecem essas desigualdades e invisibilidades estruturais. No pós1988 muitas leis ganharam marcos regulatórios importantes.

Os governos federais de vertente democrático-popular (2003-2015) foram fundamentais para fazer avançar nesses marcos regulatórios importantes. Dentre eles pode-se citar (1) a Lei 10.639/2003 que alterou a LDB (lei 9.394/96) para incluir no currículo oficial da rede de ensino a obrigatoriedade do estudo da história e cultura afro-brasileira. No ano de 2008, a Lei 11.645 alterou novamente a LBD para incluir no currículo a obrigatoriedade do estudo da história e cultura dos povos indígenas; (2) A Lei Maria da Penha (Lei 11340/06) que cria mecanismos para coibir a violência doméstica e familiar contra a mulher, nos termos do $\S 8$ o do art. 226 da Constituição Federal de 1988; (3) o Decreto 4.887/03 que "Regulamenta o procedimento para identificação, reconhecimento, delimitação, demarcação e titulação das terras ocupadas por remanescentes das comunidades dos quilombos de que trata o art. 68 do Ato das Disposições Constitucionais Transitórias da CF/1988"; (4) a Lei 150/2015 que regulamenta e garante direitos aos empregados domésticos. No âmbito da justiça uma importante conquista foi a Resolução 175/2013 do Conselho Nacional de Justiça, que garantiu aos casais homoafetivos o direito de se casarem no civil.

Esses são exemplos de avanços que mexem na histórica estrutura de desigualdades de gênero/raça/orientação sexual e privilégios de classe/status tratados neste artigo. Contudo, embora esses governos tenham apenas iniciado mudanças com a potencialidade de transformação da estrutura de longa duração das desigualdades hierarquizantes da sociedade brasileira, elas conseguiram criar um sentimento de ódio na elite, que reeditou suas práticas de histórica violência e depuseram o Governo de Dilma Rousseff legitimamente eleito. Sem nos adentrarmos nos meandros desse processo, o que se quer destacar é que a cultura política do anticomunismo, combate à corrupção e defesa da tradicional família brasileira voltaram à pauta e camuflaram os retrocessos em voga no País, evitando mais uma vez o avanço no processo de democratização da sociedade brasileira.

\section{CONSIDERAÇÕES FINAIS}

O presente artigo buscou enfrentar o desafio de pensar a violência presente na forma de condução dos rumos do Brasil nos períodos colonial, imperial e republicano, inspirada em Fernand Braudel, e no conceito de longa duração, tal qual ressignificado pelo campo da História das Mentalidades. O que se pretendeu mostrar é que, se inicialmente o colonizador 
português usou da violência no processo de exploração do País, não se pode atribuir todas as desigualdades a esse sistema, pois conforme indicado, quando se forma uma elite brasileira capaz de fazer escolhas para o modo de organização do Brasil no pós-Independência e, sobretudo, na República, essa elite nacional optou por aprofundar as desigualdades de cunho etnicorracial, de gênero e de orientação sexual e de classe/status. Ou seja, a violência que chegou com as caravelas se aprofundou nos séculos subsequentes, estruturando uma sociedade profundamente iníqua, patriarcal, sexista, machista e homofóbica.

Contudo, o poder de resistência dos grupos atingidos por essas práticas também se fez perceber, e muitas conquistas foram alcançadas num processo que tem combinado avanços e retrocessos. A denúncia dessas práticas históricas de violência das elites é fundamental para que se perceba que sempre que aquelas se veem em risco de perder seu status quo ou de melhoria nas condições de existência dos grupos subalternizados, elas lançam mão de pautas como a luta anticomunista, contra a corrupção e contra as ameaças aos valores da família tradicional. Assim, se no início deste artigo mencionamos uma fala de denúncia de uma certa violência da população brasileira, o que se pode afirmar é que essa violência é parte estruturante de como as elites econômicas e políticas do Brasil se constituíram e mantiveram seus lugares de poder e prestígio, através de um bem montado aparato que não apenas estrutura as relações desiguais na política e na economia mas, também, de forte poder nas relações simbólicas que os coloca como os naturais cidadãos a terem direitos no País.

\section{REFERÊNCIAS}

ALMEIDA, Alfredo Wagner Berno de. Quilombos: sematologia face a novas identidades. In: SMDDH; CCN. (Org.). Frechal terra de preto: quilombo reconhecido como reserva extrativista. São Luís, 1996, p. 11-19.

ANDRADE, Mário. O movimento modernista. In: BERRIEL, Carlos Eduardo (Org.). Mário de Andrade hoje. São Paulo: Ensaio, 1990 [1942]. (Cadernos Ensaio. Grande Formato, 4).

ARENDT, Hannah. Sobre a violência. Rio de Janeiro: Relumé-Dumará, 1994.

ATLAS da violência 2017. Disponível em:

<http://www.ipea.gov.br/atlasviolencia/download/2/2017>. Acesso em 10. jul.2017.

AZEVEDO, Célia M. M. de. Onda negra, medo branco: o negro no imaginário das elites do século XIX. São Paulo: Annablume, 2004.

BOSI, Alfredo. Dialética da colonização. São Paulo: Companhia das Letras, 1992. 
BROOKSHAW, David. Raça e cor na literatura brasileira. Porto Alegre: Mercado Aberto, 1983.

BUTLER, Judith. Quadros de guerra: quando a vida é passível de luto? Tradução Sérgio Lamarão e Arnaldo Marques da Cunha. Rio de Janeiro: Civilização Brasileira, 2015.

CARDOSO, Ciro Flamarion; VAINFAS, Ronaldo (Org.). Domínios da história. Rio de Janeiro: Campus, 1997.

CARDOSO, Fernando Henrique. Apelo ao bom senso. 02 abr. 2017. Disponível em: $<$ http://opiniao.estadao.com.br/noticias/geral,apelo-ao-bom-senso,70001723141>. Acesso em: 20 jun. 2017.

CARNEIRO, Sueli. Gênero e raça. In: BRUCHINI, Cristina; UNBEHAUM, Sandra G. (Org.). Gênero, democracia e sociedade brasileira. São Paulo: Fundação Carlos Chagas / Ed. 34, 2002. p. 167-194.

CARVALHO, José M. Os bestializados: o Rio de Janeiro e a República que não foi. São Paulo: Companhia das Letras, 1987.

CRENSHAW, Kimberlé. Documento para o Encontro de Especialistas em Aspectos da Discriminação Racial relativos ao Gênero. Estudos Feministas [online], n. 1, p. 171-188, 2002. Disponível em: < http://www.scielo.br/scielo.php?pid=S0104026X2002000100011\&script=sci_abstract\&tlng=pt>. Acesso em: 02 jun. 2017. FAORO, Raymundo. Os donos do poder. 10. ed. v. 2. São Paulo: Globo / Publifolha, 2000 [1925]. (Grandes Nomes do Pensamento Brasileiro).

FERNANDES, Florestan. A função social da Guerra na sociedade Tupinambá. 3. ed. São Paulo: Globo, 2006.

FIGUEIREDO, Luciano Raposo. A corrupção no Brasil Colônia. In: AVRITZER Leonardo et al. Corrupção: ensaios críticos. Belo Horizonte: Editora da UFMG, 2008, p. 209-218.

FONTELES DUARTE, Ana Rita. Gênero e comportamento a serviço da Ditadura Militar: uma leitura dos escritos da Escola Superior de Guerra. Diálogos - Revista do Departamento de História e do Programa de Pós-Graduação em História, vol. 18, núm. 1, enero-abril, 2014, p. 75-92, Universidade Estadual de Maringá. Disponível em:

<http://www.redalyc.org/pdf/3055/305531755005.pdf>. Acesso em: 20 out. 2017.

GOMES, Angela M. de Castro. A invenção do trabalhismo. Rio de Janeiro: Editora FGV, 2005.

GOMES, Flávio dos S. Histórias de quilombolas: mocambos e comunidades de senzalas no Rio de Janeiro, século XIX. São Paulo: Companhia das Letras, 2006.

GOMES. Lílian C. B. Justiça seja feita: direito quilombola ao território. Belo Horizonte, 2009. Tese de Doutorado (Faculdade de Filosofia e Ciências Humanas) Universidade Federal de Minas Gerais (mimeo). 
GUISOLPHI Anderson José. As marchas da família com Deus pela liberdade: ideologias e práticas católicas no golpe militar de 1964. Disponível em:

<http://bell.unochapeco.edu.br/revistas/index.php/rcc/article/view/559>. Acesso em 02 jun. 2017.

HOLSTON, James. Legalizando o ilegal: propriedade e usurpação no Brasil. Revista Brasileira de Ciências Sociais, São Paulo, ano 8, n. 21, p. 68-89, 1993.

LOURO, Guacira L. Teoria Queer: uma política pós-identitária para a educação. Estudos Feministas, 2001. Disponível em: < http://www.scielo.br/pdf/ref/v9n2/8639> Acesso em: 20 ago. 2017.

MARX, Anthony W. Making race and nation: a comparison of South Africa, the United States, and Brazil. Cambridge: Cambridge University Press, 1998.

MATOS, Marlise; PARADIS, Clarisse Goulart. Desafios à despatriarcalização do Estado brasileiro. Cad. Pagu [online]. 2014, n.43, pp.57-118. Disponível em:

<http://www.scielo.br/scielo.php?pid=S010483332014000200057\&script=sci_abstract\&tlng= pt> Acesso em: 20 out. 2017.

MATTOS, Hebe Maria. Escravidão e cidadania no Brasil monárquico. Rio de Janeiro: Jorge Zahar, 2000.

MONTE-MÔR, Roberto Luís de Melo; PAULA, João Antônio de. As três invenções de Belo Horizonte. Anuário Estatístico de Belo Horizonte. Belo Horizonte: PBH, p.27-49, 2000. MOTTA, Rodrigo Patto Sá. Comunismo e anticomunismo sob o olhar da polícia política. Locus, Revista de História. v. 16, n. 1, 2010. Disponível em: https://locus.ufjf.emnuvens.com.br/locus/article/view/976 Acesso em: 20 mar. 2017.

MOURA, Clóvis. Os quilombos e a rebelião negra. 3. ed. São Paulo: Brasiliense, 1983a. (Tudo é História, 12).

MUNANGA, Kabengele. Rediscutindo a mestiçagem no Brasil: identidade nacional versus identidade negra. Belo Horizonte: Autêntica, 2004.

NASCIMENTO, Abdias do. O quilombismo: documentos de uma militância pan-africanista. Petrópolis, RJ: Vozes, 1980.

NOVAIS, Fernando A.O Brasil nos quadros do Antigo Sistema Colonial. São Paulo: DIFEL, 1969.

PATEMAN, Carole. O contrato sexual. São Paulo: Paz e Terra, 1993.

PATTO, Maria H. S. Estado, ciência e política na Primeira República: a desqualificação dos pobres. Estudos Avançados, 13 (35), 1999. Disponível em: <

http://www.scielo.br/scielo.php?script=sci_arttext\&pid=S0103-40141999000100017> Acesso em: 18 out. 2017. 
PRADO JUNIOR, Caio. Formação do Brasil contemporâneo. São Paulo: Brasiliense; Publifolha, 2000. (Grandes Nomes do Pensamento Brasileiro).

REIS, João José. Escravos e coiteiros no quilombo do Oitizeiro: Bahia 1806. In: REIS, João José; GOMES, Flávio dos Santos (Org.). Liberdade por um fio: história dos quilombos no Brasil. São Paulo: Companhia das Letras, 1996.

RIBEIRO, João Luis. No meio das galinhas as baratas não têm razão: a lei de 10 de junho de 1835. Rio de Janeiro: Renovar, 2005.

RIGATTO, Silva Helena. Das sesmarias à função social da propriedade: um estudo de história do direito e da formação da estrutura agrária fundiária no Brasil. Tese (Doutorado em Direito) - Faculdade de Direito, Universidade Federal de Minas Gerais, Belo Horizonte, 2006.

SCHWARCZ, Lilia M. Nem preto, nem branco, muito pelo contrário: cor e raça na intimidade. In: NOVAIS; SCHWARZ (Org.). História da vida privada no Brasil: contrastes da intimidade contemporânea, v. 4. São Paulo: Companhia das Letras, 1998. p. 173-244.

SKIDMORE, Thomas E. Preto no branco: raça e nacionalidade no pensamento brasileiro. Rio de Janeiro: Paz e Terra, 1976[1974].

SOARES, Sergei. A demografia da cor: a composição da população brasileira de 1890 a 2007. In: THEODORO, Mário (Org.). As políticas públicas e a desigualdade racial no Brasil 120 anos após a Abolição. Brasília: IPEA, 2008.

STARLING, Heloisa M. M. Ditadura Militar. In: AVRITZER, Leonardo et al. Corrupção: ensaios críticos. Belo Horizonte: Editora da UFMG, 2008, p. 251-262.

VASCONCELOS, Daniela Mateus de. A exceção da justiça: razões do atraso e dos impasses da justiça de transição no Brasil. Tese (Doutorado em Ciência Política). Universidade Federal de Minas Gerais. Belo Horizonte, 2015.

VIANA, Oliveira. Evolução do povo brasileiro. São Paulo; Rio de Janeiro; Recife; Porto Alegre: Companhia Editora Nacional, 1938 [1922].

WISSENBACH, Cristina Cortez. Da escravidão à liberdade: dimensões de uma privacidade possível. In: SEVCENKO, Nicolau (Org.). República: da Belle Époque à Era do Rádio. São Paulo: Companhia das Letras, 1998. p. 131-214. (Coleção da vida privada no Brasil, 3). 